\title{
Freshwater Mussel Soft Tissue Incorporates Strontium and Radium Isotopic Signatures of O\&G Produced Water
}

BONNIE MCDEVITT ${ }^{1}$, ThOMAS J. GEEZA ${ }^{2}$, NATHANIEL R. WARNER $^{3}$

${ }^{1}$ The Pennsylvania State University, Department of Civil and Environmental Engineering, 212 Sackett Building, University Park, PA 16802, bum49@psu.edu

${ }^{2}$ The Pennsylvania State University, Department of Civil and Environmental Engineering, tjgeeza@gmail.com

${ }^{3}$ The Pennsylvania State University, Department of Civil and Environmental Engineering, nrw6@psu.edu

Oil and gas $(\mathrm{O} \& \mathrm{G})$ extraction processes in the United States generate 3.3 trillion L of produced water annually. $O \& G$ produced water is often a saline $(10-300 \mathrm{~g} / \mathrm{L})$ waste stream containing elevated concentrations of metals $(\mathrm{Ba}, \mathrm{Sr}$, $\mathrm{Pb}$ and $\mathrm{As}$ ) and radioactivity that is frequently disposed of, post-treatment, to surface waters. Freshwater mussels are the most endangered North American fauna and exhibited high mortality downstream of O\&G discharges in Pennsylvania. Previous studies reported alkaline earth metal concentration in mussel shells and soft tissue and the ability to obtain a temporal record of $\mathrm{O} \& \mathrm{G}$ impacts in mussel shells utilizing $\mathrm{Sr} / \mathrm{Ca}, \mathrm{Ba} / \mathrm{Ca}$, and ${ }^{87} \mathrm{Sr} /{ }^{86} \mathrm{Sr}$. Here, a controlled tank study was conducted on laboratory-grown adult freshwater mussels in high, medium, low and control dose tanks utilizing realistic concentrations of O\&G produced water to simulate dilution effects of a large riverine system. Water samples were collected throughout the 3-month study and analyzed for major ions and radium. Harvested mussel shells and soft tissue were separately analyzed for Ra. Soft tissue was digested, measured for major cations, trace metals, and ${ }^{87} \mathrm{Sr} /{ }^{86} \mathrm{Sr}$. Sr concentrations in soft tissue were significantly higher $(\mathrm{p}<0.05)$ in tanks with increasing dosage while other metal concentrations $(\mathrm{Ba}, \mathrm{Ca}, \mathrm{Mn}, \mathrm{Fe}$ ) reflected no differences. ${ }^{87} \mathrm{Sr} /{ }^{86} \mathrm{Sr}$ were significantly more radiogenic in the high dose tank, reflecting an O\&G signature of approximately 0.7095 while the control tank soft tissue reflected a less radiogenic ${ }^{87} \mathrm{Sr} /{ }^{86} \mathrm{Sr}$ of 0.7068 , indicating mussel incorporation and concentration of O\&G derived Sr. Initial Ra results indicated no difference in concentration of $\mathrm{Ra}$ in the soft tissue between dosage tanks. However, soft tissue in the high dose tanks did reflect a higher average ${ }^{226} \mathrm{Ra}{ }^{228} \mathrm{Ra}$ of 1.37 , compared to an average control soft tissue ${ }^{226} \mathrm{Ra} /{ }^{228} \mathrm{Ra}$ of 1.13 , towards the elevated $\mathrm{O} \& \mathrm{G}$ produced water ratio of 8.90 . Impacts to endangered species may affect $O \& G$ produced water disposal management. 